\title{
Making the Unknown or Invisible Accessible: \\ The Collaborative Development of Inclusion-Focused Open-Access \\ Case Studies for Principals and Other School Leaders
}

\author{
Kimberly Maich \\ Memorial Univerity \\ Steve Sider \\ Wilfrid Laurier University \\ Jhonel Morvan \\ Brock University \\ Déirdre M. Smith \\ Ontario College of Teachers
}

\begin{abstract}
Authors' Note
Correspondence concerning this article should be addressed to Dr. Kimberly Maich, Memorial University, Hickman Building 3056, 320 Elizabeth Avenue, St. John’s, NL A1K 3X9. Email: kmaich@mun.ca
\end{abstract}




\begin{abstract}
Gaps between research and practice exist in the field of inclusive and special education, especially around school-based leadership (e.g., principals). Research-based case studies are a way to teach and learn about disability, especially stigmatized issues such invisible disability (e.g,. intellectual disability), which may be complex with multiple stakeholders, yet difficult to access. This article reviews the collaborative process of developing and disseminating authentic case studies built on lived experiences of school principals as an example of bridging the gap between research and practice with multiple, engaging knowledge mobilization activities. Future knowledge mobilization activities, such as the development of interactive, online case-based based learning around inclusive classrooms and schools, are discussed.
\end{abstract}




\section{[Introduction]}

The research literature on education for students with developmental and intellectual disability is plentiful. However, there is often a gap between such research itself and the mobilization of this research in a practical manner to teachers, school principals, and others who work in school-based settings (Hott, Berkeley, Raymond, \& Reid, 2018). The purpose of this article is to describe the process by which a team of researchers and an organization responsible for the accreditation of teachers in Ontario, Canada engaged in a collaborative project to mobilize research on inclusive education. Although these examples of research mobilization are fundamentally based on empirical research projects developed and implemented by a research group from the Canadian Research Centre on Inclusive Education, the focus of this article is on the mobilization of these scholarly projects (e.g., Sider, Maich, \& Morvan, 2017) through emergent case studies as tools for professional learning.

The importance of this article is in its use of a case study framework as a method for mobilizing professional development for principals regarding disability and inclusion. We describe the process of collaboration and partnership to develop, vet, and mobilize case studies we wrote on leadership for inclusive schools (Sider, Maich, Morvan, Specht, $\&$ Smith, 2018). We present how a coordinated and integrated approach was able to maximize the research findings in grounded and applied ways, including how collaboration not only enhanced the quality of case study development but also highlights professional learning through case study. The case studies are particularly directed to principals who need to understand the complex issues involved with children with intellectual and developmental disabilities and other complex intersectionalities. We begin by examining disability in Canada and then turn to the literature on case studies as 
a form of knowledge mobilization. Following this we describe the process of case study development as input was provided throughout the process by various stakeholders in Ontario, Canada. We also consider the mobilization of the case studies in multiple sectors, including providing a copy of the booklet to every principal in the province of Ontario, to all faculties of education and professional associations that support principal professional learning in the province, and in academic presentations in Ontario and beyond. In the final section, we consider opportunities for further research in this area.

\section{Literature Review}

In order to consider the process of mobilizing case studies to support inclusive school leadership, it is important to first understand the context for disability in Canada. We then turn to literature that speaks to the value of case study approaches for supporting educator professional development. Finally, we examine pertinent literature on the importance of mobilizing research to inform school-based practices.

\section{Disability in Canada}

The most recent Statistics Canada Survey on Disability (2018) provided a 2017 national overview of Canadians with disabilities, including Canadians with developmental disabilities. One in five Canadians who are 15 years of age are identified with a disability that "limited them in their daily activities" (para. 1). Particularly relevant to school leaders, however, is that this prevalence increases as children age but also that $13 \%$ of the group of youths between 15 and 24 years old have disabilities. In Canadian

youth, "mental health-related ( $8 \%$ ) was the most common type of disability, followed by learning (6\%), and pain-related disabilities (4\%)" (para. 4). It is clear that disability is prominent in Canadian schools, that needs change as a function of severity, and that 
disability relates to outcomes far beyond the school years, such as employment and poverty. It is highly evident that educators need to pay attention, teach, and learn in this important area of today's complex, inclusive classrooms.

In Canada, the movement to inclusive education and to supporting all students, with disabilities or without, in the regular classroom has evolved over the past 30 years (DeLuca, 2013). Since education is a provincial area of responsibility, there tends to be a spectrum of inclusive education models across the country. These range from full and complete inclusion to models that provide for congregated settings for students with disabilities. Research efforts on inclusive education in Canada have tended to focus on teacher preparation (e.g., Bennett, Dworet, \& Weber, 2013; McCrimmon, 2015) and teacher resources and supports (e.g., Calder Stegemann \& Aucoin, 2018, Maich, 2015; Maich \& Hill, 2017). Only in the past 10 years, greater attention has been given to research on how school principals support inclusive schools for students with disabilities (Irvine, Lupart, Loreman, \& McGhie-Richmond, 2010; Sider et al., 2017; Zaretsky, Moreau, \& Faircloth, 2008).

Case studies are one way of making this teaching and learning happenespecially relevant when we cannot directly engage with certain students, environments, interactions, or disabilities. This approach may be particularly applicable to what is often termed invisible disability, defined as "disabilities that interfere with day-to-day functioning but do not have a physical manifestation" (Mullins \& Preyde, 2013, p. 148) such as developmental disabilities, intellectual disability, learning disorders, mental health isssues, and chronic pain. Negative perceptions and stigmatized responses to 
invisibility may be particularly evident, and specific education is needed for society, including schools and for educators, including school leaders.

\section{Case Studies}

Case studies have "a rich, strong history as an effective, engaging, student-centred instructional strategy to supplement more traditional approaches to knowledge transmission" (Maich, 2015, p. xiv), helping information to come to life for its learners in a real-world, practical manner (Foran, 2001; Hackney, McMaster, \& Harris, 2003). Whether fictional or authentic, case studies demonstrate and dramatize humanity and its stories, conflicts, issues, and complexities in an easily accessible way (Davis \& Wilcox, 2003; Parker, Smith, \& Goldblatt, 2009). The open-ended nature of case study provides learners with the opportunity to discuss, debate, probe, role-play, evaluate, prioritize, critique, and synthesize, while comparing facts, issues, and dilemmas (Barroso \& Abreu, 2015; Foran, 2001; Penn State University, 2006).

Case studies have been used extensively in teacher pre-service education and inservice professional learning. They have been used, often, in professional learning communities to support teachers' ongoing learning (Watson, 2014). Case studies have been particularly helpful in supporting learning about special education (Calder Stegemann \& Aucoin, 2018; Maich \& Hill, 2017). However, there has been limited use of case studies to examine situations involving children with less visible issues such as learning, intellectual, mental health, and developmental disabilities — whether labelled or implied. Case studies would be particularly helpful in this area due to the complex issues implicated and the multiple stakeholders involved (Simplican, Leader, Kosciulek, \& Leahy, 2015). 
Case studies have also been used in the professional learning of school principals

(e.g., Wettlaufer \& Sider, 2019). Those responsible for the professional learning of principals have found that case studies support reflective practices for educators, particularly on issues related to ethical dilemmas and social justice (Gardiner \& Tenuto, 2015; Hanhimäki \& Tirri, 2009). Case studies that are situated around a particular “disorienting dilemma” (Mezirow \& Taylor, 2009) or "critical incident” (Yamamoto, Gardiner, \& Tenuto, 2014) provide opportunities for principals to consider their own practices in relationship to such cases.

Despite the benefits of case studies as a learning tool for principals, they have been only used minimally in the professional learning programs of principals, specifically in the context of students with disabilities (Griffin \& Ryan, 2018; Sider et al., 2017). In our review of the literature, no case studies were identified that are specifically crafted for school principals about students with intellectual and developmental disabilities. This is surprising, considering the complex and interconnecting issues that are present with students with neurodevelopmental disabilities and the resulting implications for school principals. We commenced a research and knowledge mobilization project to address the limited number of case studies that are written for the intersection of school leadership and special education, particularly for complex disabilities and interconnecting issues.

\section{Knowledge Mobilization}

Knowledge - always an important outcome of education — is considered to be a dynamic paradigm framed by 21 st-century skills that needs effective management and distribution (Hannay \& Earl, 2012). Knowledge mobilization is one step in the process of knowledge creation, described in part as disseminating academic or professional research 
into the community and society to enhance its benefits and impact though methods such accessible publications (Cooper, Rodway, \& Read, 2018). Educators and educational organizations must do their part and "create the conditions for educators to engage in knowledge construction and dissemination processes" (Hannay \& Earl, 2012, p. 324). Parker, Smith, and Goldblatt (2009) described a successful example involving university and professional college collaboration using case studies to mobilize knowledge and found that one outcome was the value of such experiences for a range of roles, including school leaders such as principals. Cross, Rosenbaum, Grahovac, Kay, and Gorter (2015) added that dissemination plans should be developed actively and early within a strong partnership. They also discovered that related material should inspire and persuade, providing emotional connections inspiring users of its share-worthiness.

Clearly, supporting students with disabilities in inclusive schools is a key issue in Canada, North America, and internationally. Case studies provide innovative and timely resources to support knowledge mobilization in this area. In the following section, we describe the process of developing and mobilizing case studies to support principal development in leading inclusive schools.

\section{Our Partnership and the Collaborative Process}

Between 2015-2018, competitive funding was obtained for a national study to examine the experiences of school principals in the area of special education, including 285 principals from across English-speaking and French-speaking Canada. The research results of this study were reported elsewhere (Sider et al., 2017; Sider, Morvan, Maich, Specht, \& McGhie-Richmond, in press). The research partnership consisted of faculty from universities across Canada and principals' and teaching associations. One key 
partner was the Ontario College of Teachers (OCT). The OCT has responsibilities related to continuing professional education for certified teachers, Principal Qualification Programs, and initial teacher education programs professional that lead to professional certification in Ontario (Parker, Smith, \& Goldblatt, 2009). Education is a provincial responsibility in Canada, so the OCT supports educators in the province of Ontario. There are more than 230,000 teachers certified by the Ontario College of Teachers; Ontario is the largest province by population in Canada and is an international leader in education (Darling-Hammond \& Rothman, 2011). Given the prominent role of the OCT in Ontario, and Ontario's educational leadership on the global scale, it was particularly important to have the involvement of the OCT in this research study. The OCT agreed to participate in a knowledge mobilization aspect of the research study that included the development and dissemination of a formal booklet of case studies that emerged from the results of this study.

\section{Case Study Development}

The development of these case studies began with a review of qualitative data that emerged from interviews with 48 of the participants in the above-described study. These 48 participants regularly described critical incidents that affected them in their schoolbased leadership roles as vice-principals or principals (the term principals is used inclusively henceforth) specific to working with students with special education needs. Themes were developed from this data set and the research team then used these themes to develop case studies. Each case study was based on the interview data; however, any information that could potentially identify individual participants was removed. For most of the case studies, the cases were a synthesis or aggregate of different critical incidents, 
thus further protecting the identification of involved participants. Eight complete case studies were developed throughout 2016. The eight cases included a broad spectrum of special education needs including developmental disabilities, physical disabilities, and significant behavioural issues - including issues that are implied but are not (yet) evidently diagnosed (clinically) or identified through school-based practice. The cases also presented various areas that overlap with special education such as teacher efficacy, relationship development, cultural and linguistic aspects, and parent engagement.

The research team shared the draft case studies among themselves to ensure that the narrative text was clear, understandable, and compelling. After the case studies had been confirmed in this stage of development, and in partnership with the Ontario College of Teachers and the Canadian Research Centre on Inclusive Education, a knowledgesharing day was coordinated in October 2016 at the Canadian Research Centre on Inclusive Education in London, Ontario, Canada. The Canadian Research Centre on Inclusive Education is a national consortium of faculty at universities as well as representatives from diverse school systems across Canada in an effort to support inclusive education. There were 25 participants at the knowledge-sharing day, including principals from different school systems, university faculty, research assistants, and the manager of the education unit for the OCT. The participants worked in groups to read the cases and provide input, particularly into the authenticity and usefulness of the cases. This validating exercise provided confirmation that the case studies reflected the lived experiences of the principals who participated in the knowledge-sharing day. The research team completed minor edits of the cases and incorporated questions that the 
participants had provided that could be included with the case studies as part of the reflective learning component.

A second knowledge-sharing day was coordinated at the headquarters of the Ontario College of Teachers in January 2017. The research team worked with the manager of the education unit for the OCT to present the cases to 45 participants who were responsible for the professional learning of principals in the province of Ontario. These participants represented both English- and French-language school systems in Ontario. The process was similar to that of the first knowledge-sharing day, as described above. The cases were validated through small groups who concurred, after reviewing the cases, that they reflected the types of issues and situations that principals experience with students with special education needs on a day-to-day basis in their local schools. In addition, the groups provided commentaries on the cases that could be included to provide expert opinions. At the end of the knowledge-sharing day, the OCT gathered the feedback from the discussion groups and the commentaries that were developed and began a process of developing the materials into a format that could be shared with principals and with those responsible for their professional learning across the province. As these revisions occurred, they were reviewed with the research team to ensure that the case studies, questions, and commentaries were aligned with the research and the knowledge mobilization strategies.

\section{Case Study Mobilization}

In 2018, the case studies were printed in a 63-page booklet format that was available in English and French (see Figure 1) and published open-access online (see Morvan \& Smith, 2020 [this issue]). 
[Insert Figure 1 about here]

Given that Canada is a bilingual country with two official languages, it was crucial that the case studies be available in English and French. As noted earlier, there are English and French public-school systems in Ontario, so it was important that the resource be available for English and French-speaking principals. Every principal in Ontario, all directors of education, and organizations involved in principal professional learning received a digital or hard copy of the booklet. The OCT and Canadian Research Centre on Inclusive Education published the booklet in digital form on their websites. School organizations from across Canada were made aware of the electronic and hard copies of the case study booklet and invited to make use of it. The specific knowledge mobilization strategy that was employed for distribution of this resource in Ontario was diverse and varied (see Morvan \& Smith, 2020 [this issue]).

\section{Case Study Uptake}

In the 2018-2019 school year, the research team made presentations at various educational forums (e.g., Ontario Council for Exceptional Children; Ontario Educational Research Association, National Institute for Learning Development, Division on Autism and Developmental Disabilities) and provided support on how to use the case studies for principals' professional learning. These conferences and educational forums provided an opportunity to further mobilize the case studies to other educational stakeholders across Canada and the United States.

The feedback on the use of the case resource booklet received from initial teacher education programs, continuing teacher education courses, Principal Qualification Programs and from the district school boards has been very positive. The French 
language community immediately embraced the case booklet, given the limited resources available that are developed in French and that reflect the Ontario educational context. The case booklet has also been used as a core educative resource within English language principal preparation programs. One provincial organization led a session with all facilitators of the Principal Qualification Program (PQP) that focused on the use and integration of the case booklet within all of their PQP courses. Each year, approximately 14,000 educators enrol in special education Additional Qualification (AQ) courses in Ontario, further professional development for certified teacher. The case booklet is also being used within these special education AQ courses as an inclusive stance is explicitly outlined in these course guidelines issued by OCT. Requests for the development of another similar resource with new cases have also been received.

\section{Process, Outcomes, and Discussion}

School leaders who read, discuss, and learn from these cases are introduced to a number of issues, elements, and terms that can be related to - or entwined withsupporting students with invisible disabilities such as: selective mutism, English language learners, print-based disabilities, learning challenges, behaviour challenges, learning disabilities, anxiety issues, and family crises. The cases invite critical exploration into educators' beliefs, conceptualizations of learners, and educational practices and policies. The cases also invite inquiry into the many interrelated dimensions inherent within inclusive school cultures. The intersection of school leadership, inclusion, and school culture is an important area requiring further research as school systems endeavour to support all students (Inclusive Education Canada, 2013; Sider et al., in press).

\section{The Process}


The experiences related to developing and validating the case studies mentioned in this article have proved to be useful and rewarding for school principals and other educators. Not only have the cases contributed to significant knowledge mobilization, a key aspect of research, but they have also filled a gap in the research literature around case study availability relevant to students with intellectual and developmental disabilities. Additionally, involving multiple university researchers, a self-regulatory body for the teaching profession like the Ontario College of Teachers, a research centre, and close to 100 educators including school principals demonstrated how effective collaboration could be to ultimately benefit students with special needs including those with intellectual and developmental disabilities. This process was a learning experience for all involved and modelled for principals the importance of collaboration in working with teachers, educational assistants, and parents within the school for the benefit of students with intellectual and developmental disabilities (Villeneuve et al., 2013)

\section{The Outcomes}

In addition to the process-related advantages outlined above, case studies can also provide an opportunity to move beyond the traditional focus on the legal aspect (the formalities) related to intellectual and developmental disabilities. Case studies provide a way out of this solely legal frame and return voices to participants to describe critical incidents that they have been involved with as school principals, specifically to working with students with special education needs. In addition to the benefits of partnerships and collaboration, this project has the merit of demonstrating that case studies are an effective way to support professional learning opportunities but also pointing to the need for more 
cases specific to students with intellectual and developmental disabilities due to the complex nature of these situations.

A key outcome of this partnership was the case study booklet (Sider et al., 2018). We consider this booklet the key piece of knowledge mobilization. Creating the case study book engaged us in the model of extending our existing networks (Campbell, Pollock, Briscoe, Carr-Harris, \& Tuters, 2017). We developed a gap assessment, produced the appropriate product, and have disseminated it. Cooper (2014) stated that the best way to address the research-practice gap is for research to be mobilized. The complexity of issues associated with the inclusive education of students with intellectual and developmental disabilities will be addressed through real-life situations and expert questions raised in this product.

The development of the case studies and their mobilization to principals, educational organizations, and future school leaders across the province of Ontario has led to a number of follow-up activities. As a result of the importance of the topic and the success of mobilizing knowledge through the case studies, the research team applied for and received further national research funding to hold a conference entitled Exploring Intersectionalities for Leadership and School Inclusion on June 1, 2019 in Vancouver, British Columbia. The case studies were used at the conference, along with keynote and research-focused presentations, to further mobilize principals and those responsible for their professional learning from across Canada. An important new aspect to this work is the consideration of how Indigenous perspectives can inform the work of principals with students with special education needs. An anticipated outcome of the conference is a collective effort from researchers across Canada to further engage with research on how 
principals can effectively support students with special education needs in inclusive schools.

Members of the research team have also received national government funding to begin to develop interactive case studies related to special education and school leadership. This research project will present cases through a more dynamic, web-based process that will provide principals with branching scenarios and multimedia resources to support their learning. This is an area of case study application that has been developed in medicine and business training but not in education. It is expected that the immersive experience of engaging with these types of case studies will further enhance principals' learning outcomes.

A further outcome of the research and the mobilization activities has been expanded opportunities to engage with international partners in this area of research. Members of the research team are engaging with opportunities in Europe, Africa, and the Caribbean that will explore the intersection of school leadership, special education, and the use of case studies as an effective way to mobilize knowledge on this research.

\section{Discussion}

It is a clearly evident that there is a tendency to examine special education as a separate and isolated entity (Sider et al., in press). While case studies have been used extensively in teacher pre-service education and in-service professional learning as well as in professional learning communities to support teachers' ongoing learning (Watson, 2014), there has been limited use of case studies to examine situations involving children with intellectual and developmental disabilities. However, research has revealed that case studies have been particularly helpful in supporting learning about special education 
(Calder Stegemann \& Aucoin, 2018; Maich \& Hill, 2017). This article exposes some of the various reasons why there has been limited use of case studies to examine situations involving children with intellectual, developmental, and other invisible disabilities, even though case studies would be particularly helpful in this area due to the complex issues and multiple stakeholders (Simplican et al., 2015). Further, case studies can be used to support principals' examination of personal perspectives on inclusion and how to effectively lead change in schools (Inclusive Education Canada, 2013).

One primary reason that there is limited use of case studies with a focus on special needs and exceptionalities is that it requires commitment from multiple stakeholders. It takes time to build partnerships and establish relationships that may yield relevant case studies. True collaboration and multiplicity of voices provide opportunities for researchers, practitioners, and different stakeholders to establish a process like the one described in this article. In much the way we collaborated across educational sectors, principals, too, need to build collaborative teams that engage in the change-making process required to foster inclusive schools: "A critical stage for accomplishing inclusive schools is establishing collaborative teams within your school that act as decision making bodies that reference the philosophy and standard of inclusion" (Inclusive Education Canada, 2013, p. 3).

\section{Conclusion}

The process of collaboration and partnership to develop, vet, and mobilize case studies brings forth new knowledge that can address existing gaps between the research itself and the mobilization of this research to educators, particularly school principals looking to orchestrate authentic inclusive education. Since "all knowledge is political and 
... research should be aimed at eliminating social injustice, particularly related to ethnicity, gender, sexual orientation, disability and other marginalized groups" (SavinBaden \& Howell Major, 2013, p. 60), this process is well worthwhile, as it helps facilitate insightful knowledge mobilization.

Through this experience, the research team makes it clear that case studies provide alternatives to the traditional legal frame around special education. They model how to give voices to participants describing critical incidents that they have encountered specifically in their work with students with special education needs. One of the key lessons learned through the process is that partnerships and collaboration are indispensable pillars for such models to be successful. Through this project, it is safe to say that case studies present an effective way to support professional learning opportunities. At the same, this collaborative endeavour points to the need for more cases specific to supporting complex students with intellectual and developmental disabilities, and to help make the unknown and invisible, known. This framework of case studies will provide more diversified training opportunities for those involved in the complex area of special needs education. 


\section{References}

Barroso, C., \& Abreu, W. (2015). Developing ethical thinking in clinical settings: A case study. Procedia-Social \& Behavioural Sciences, 171, 661-667. doi:10.1016/j.sbspro.2015.01.175

Bennett, S., Dworet, D., \& Weber, K. (2013). Special education in Ontario schools (7th Ed.). St. Davids, ON: Highland Press.

Calder Stegemann, K., \& Aucoin, A. (Eds.). (2018). Inclusive education: Stories of success and hope in a Canadian context. Toronto, ON: Pearson Canada.

Campbell, C., Pollock, K., Briscoe, P., Carr-Harris, S., \& Tuters, S. (2017). Developing a knowledge network for applied education research to mobilise evidence in and for educational practice. Educational Research, 59(2), 209-227.

doi:10.1080/00131881.2017.1310364

Cooper, A. (2014). Knowledge mobilisation in education across Canada: A cross-case analysis of 44 research brokering organisations. Evidence \& Policy, 10(1), 29-59. doi:10.1332/174426413X662806

Cooper, A., Rodway, J., \& Read, R. (2018). Knowledge mobilization practices of educational researchers across Canada. Canadian Journal of Higher Education, 48(1), 1-21. doi:10.7202/1050839ar

Cross, A., Rosenbaum, P., Grahovac, D., Kay, D., \& Gorter, J. W. (2015). Knowledge mobilization to spread awareness of the "F-words" in childhood disability: Lessons from a family-researcher partnership. Child: Care, Health and Development, 6, 947-953. doi:10.1111/cch.12249

Darling-Hammond, L., \& Rothman, R. (2011). Teacher and leader effectiveness in highperforming education systems. Stanford, CA: Alliance for Excellence Education 
and Stanford Center for Opportunity Policy in Education. Retrieved from https://edpolicy.stanford.edu/sites/default/files/publications/teacher-and-leadereffectiveness-high-performing-education-systems.pdf

Davis, C., \& Wilcox, E. (2003). Teaching materials using case studies. Liverpool, UK: UK Centre for Materials Education. Retrieved from www.materials.ac.uk/guides/1-casestudies.pdf

DeLuca, C. (2013). Toward an interdisciplinary framework for educational inclusivity. Canadian Journal of Education, 36(1), 305-348.

Foran, J. (2001). The case method and the interactive classroom. Thought \& Action, 17(1), 41-50. Retrieved from ERIC database (Doc. EJ63115), www.eric.ed.gov

Gardiner, M. E., \& Tenuto, P. L. (2015). Reflections of practicing school principals on ethical leadership and decision-making: Confronting social injustice. The Journal of Values-Based Leadership, 8(2), Article 6. Retrieved from https://scholar.valpo.edu/jvbl/vol8/iss2/6

Griffin, D., \& Ryan, J. (Eds.). (2018). Case studies for inclusive educators and leaders. Burlington, ON: Word and Deed Publishing.

Hackney, R., McMaster, T., \& Harris, A. (2003). Using cases as a teaching tool in IS education. Journal of Information Systems Education, 14(3), 229-234.

Hanhimäki, E., \& Tirri, K. (2009). Education for ethically sensitive teaching in critical incidents at school. Journal of Education for Teaching, 35(2), 107-121. doi:10.1080/02607470902770880 
Hannay, L. M., \& Earl, L. (2012). School district triggers for reconstructing professional knowledge. Journal of Educational Change, 13, 311-326. doi:10.1007/s10833012-9185-2

Hott, B. L., Berkeley, S. L., Raymond, L. P., \& Reid, C. C. (2018). Translating intervention research for students with mild disabilities to practice: A systematic journal analysis. Journal of Special Education, 52(2), 67-77. doi: $10.1177 / 0022466918759338$

Inclusive Education Canada. (2013). School principals leading the way to inclusive schools: Implementation steps for moving forward. Retrieved from https://inclusiveeducation.ca/wp-content/uploads/sites/3/2013/07/SchoolPrincipals-Leading-the-Way-to-Inclusive-Education.pdf

Irvine, A., Lupart, J., Loreman, T, \& McGhie-Richmond, D. (2010). Educational leadership to creative authentic schools: The experience of principals in a Canadian rural school district. Exceptionality Education International, 20(2), 7088.

Maich, K. (2015). Early learners in preschools and kindergartens: 50 case stories in child development, inclusion, collaboration and special needs. Toronto, ON: Pearson Education.

Maich, K., \& Hill, R. (2017). Special education case studies. Toronto, ON: Oxford University Press.

McCrimmon, A. (2015). Inclusive education in Canada: Issues in teacher preparation. Intervention in School and Clinic, 50(4), 234-237. 
Mezirow, J., \& Taylor, E. W. (2009). Transformative learning theory. In J. Mezirow \& E. W. Taylor (Eds.), Transformative learning in practice: Insights from community, workplace, and higher education (pp. 18-31). San Francisco, CA: John Wiley \& Sons.

Morvan, J., \& Smith, D. M. (2020). Case inquiry as critical praxis: Supporting intersectionality within inclusive leadership practices. Exceptionalities Education International, 30(2), $\mathrm{xx}-\mathrm{xx}$.

Mullins, L., \& Preyde, M. (2013). The lived experience of students with an invisible disability at a Canadian university. Disability \& Society, 28(2), 147-160. doi:10.1080/09687599.2012.752127

Parker, D. C., Smith, D., \& Goldblatt, P. (2009). Teacher education partnerships: Integration of case studies within an initial teacher education program. Brock Education, 18(2), 96-113. Retrieved from https://journals.library.brocku.ca/brocked/index.php/home/issue/view/18

Penn State University. (2006). Using cases in teaching [Web page]. Retrieved from http://tlt.its.psu.edu/suggestions/cases (Now available at archive.org)

Savin-Baden, M., \& Howell Major, C. (2013). Qualitative research: The essential guide to theory and practice. New York, NY: Routledge.

Sider, S., Maich, K., \& Morvan, J. (2017). School principals and students with special education needs: Leading inclusive schools. Canadian Journal of Education, 40(2). Retrieved from http://journals.sfu.ca/cje/index.php/cjerce/article/view/2417 
Sider, S., Maich, K., Morvan, J., Specht, J., \& Smith, D. (2018). Exploring leadership practices through case inquiry: Supporting inclusive schools. Retrieved from https://www.inclusiveeducationresearch.ca/docs/ExplLdrshpPrctcsCseInqry_en web_bklt.pdf

Sider, S., Morvan, J., Maich, K., Specht, J., \& McGhie-Richmond, D. (in press). Between, betwixt, and amongst: Intersectionalities where school leadership and inclusive schools meet. In C. McGregor \& S. Bedi (Eds.), Diverse leadership landscapes: Exploring the terrain. Kingston, ON: Queen's University Press.

Simplican, S. C., Leader, G., Kosciulek, J., \& Leahy, M. (2015). Defining social inclusion of people with intellectual and developmental disabilities: An ecological model of social networks and community participation. Research in Developmental Disabilities, 38, 18-29.

Statistics Canada. (2018). Canadian survey on disability, 2017. Retrieved from https://www150.statcan.gc.ca/n1/en/daily-quotidien/181128/dq181128aeng.pdf?st=3QJZpGXx

Villeneuve, M., Chatenoud, C., Minnes, P., Perry, A., Hutchinson, N. L., Frankel, E. B., ... Weiss, J. (2013). The experience of parents as their children with developmental disabilities transition from early intervention to kindergarten. Canadian Journal of Education, 36(1), 4-43.

Watson, C. (2014). Effective professional learning communities? The possibilities for teachers as agents of change in schools. British Educational Research Journal, 40(1), 18-29. 
Wettlaufer, J., \& Sider, S. (2019). The importance of trust in school improvement professional learning communities. Journal of Cases in Educational Leadership. doi:10.1177/1555458919826220

Yamamoto, J. K., Gardiner, M. E., \& Tenuto, P. L. (2014). Emotion in leadership: Secondary school administrators' perceptions of critical incidents. Educational Management Administration \& Leadership, 42(2), 165-183.

Zaretsky, L., Moreau, L., \& Faircloth, S. (2008). Voices from the field: School leadership in special education. The Alberta Journal of Educational Research, 54(2), 161177. 


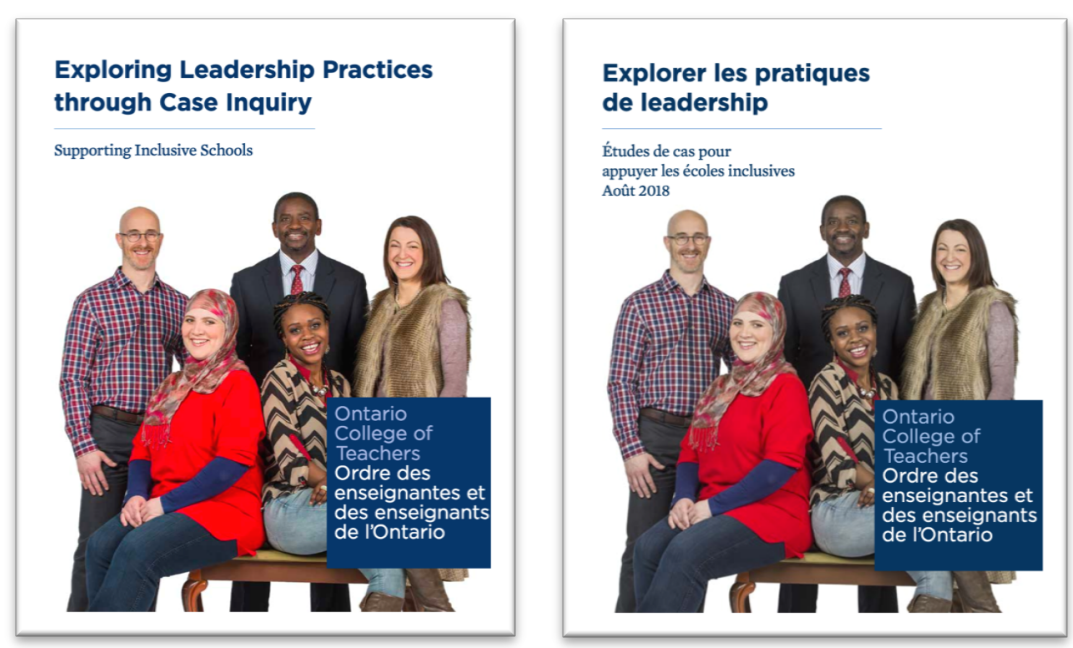

Figure 1: Case Study Booklet (Sider et al., 2018) in English and French. 